\title{
Melatonin: A Potent Therapeutic Candidate in Degenerative Neural Damages
}

\author{
Zeeshan Ahmad Khan 1,2,3*, Yunkyung Hong ${ }^{1,2,3 *}$, Jeonghyun Choi ${ }^{1,2,3,4}$, \\ Youngjeon Lee ${ }^{5}$, Yunho Jin ${ }^{1,2,3,4}$, and Yonggeun Hong ${ }^{1,2,3,4,6}$ \\ 'Department of Physical Therapy, College of Healthcare Medical Science \& Engineering, Inje University, Gimhae, Korea \\ ${ }^{2}$ Biohealth Products Research Center (BPRC), Inje University, Gimhae, Korea \\ 3Ubiquitous Healthcare \& Anti-aging Research Center (u-HARC), Inje University, Gimhae, Korea \\ ${ }^{4}$ Department of Rehabilitation Science, Graduate School of Inje University, Gimhae, Korea \\ ${ }^{5}$ National Primate Research Center, Korea Research Institute of Bioscience and Biotechnology (KRIBB), Cheongju, Korea \\ ${ }^{6}$ Department of Medicine, Division of Hematology/Oncology, Harvard Medical School-Beth Israel Deaconess Medical Center, Boston, MA, USA
}

\begin{abstract}
The hormone of darkness "melatonin" has shown extraordinary potential. Owing to versatile properties which include, but are not limited to, strong antioxidation, anti-inflammatory, anti-apoptotic, and chronotherapeutic action has generated a great deal of interest as a therapeutic drug for various diseases especially neural damage and neurodegenerative diseases. Melatonin has shown to be effective in arresting neurodegeneration in experimental models of Alzheimer's, Huntington's, and Parkinson's disease, subarachnoid hemorrhage, and ischemic stroke. In this article, the authors review the role of melatonin in neural damage and associated diseases. Briefly, we will discuss the function and protective role of melatonin in the central and peripheral nervous systems. Subsequently, an overview of the role of melatonin in endoplasmic reticulum and mitochondria in neural tissues along with possible biological pathways will be addressed. Finally, we will review the action of melatonin on programmed cell death and its probable molecular mechanism.
\end{abstract}

Key Words: Melatonin; Neural damage; Antioxidant; Apoptosis; Therapeutics

Received: July 28, 2020 Accepted: August 21, 2020

Corresponding author: Yonggeun Hong, DVM, PhD, Department of Rehabilitation Science, Graduate School of Inje University, 197 Inje-ro, Gimhae 50834 , Korea.

Tel: 82-55-320-3681, Fax: 82-55-329-1678, E-mail: yonghong@inje.ac.kr

*These authors contributed equally to this work.

(a) This is an Open Access article distributed under the terms of the Creative Commons Attribution Non-Commercial License (https://creativecommons.org/licenses/by$\mathrm{nc} / 4.0)$ which permits unrestricted non-commercial use, distribution, and reproduction in any medium, provided the original work is properly cited.

\section{INTRODUCTION}

Melatonin ( $N$-acetyl-5-methoxytryptamine), commonly known as the sleep hormone or hormone of darkness, is a phylogenetically conserved molecule with numerous versatile and diverse functions [1-4]. In general, melatonin has; 1 ) antioxidant activity primarily by its free radical scavenging, 2) antiapoptotic property mostly by blocking caspase- 3 cleavage and mitochondrial permeability transition pore opening, 3) anti-inflammatory action generally by inhibiting inflammasome activation, and 4) chronobiotic abilities by acting as a sleep inducer [5-11]. Moreover, in different organisms, the function of melatonin includes maintenance of gut motility, circadian and sedation (sleep) activity, immune modulation, osmoregulation, shoaling and schooling, locomotor activity, regulation of cell cycle, food intake, thermal preference manage- ment, skin pigmentation, reproduction and growth [12-17]. This multifunctional and multipotent indolamine is primarily produced in the pineal gland in a circadian manner synchronized with photoperiodic information received via the retinohypothalamic pathway [18]. Recent studies have proved that melatonin can be synthesized from several extra pineal sites like retina, brain, gut, testis, and ovary [4,19-22]. The presence of melatonin receptors in almost all of the vertebrate tissues is reported, which is an indicator of the functional prowess of melatonin [22-26]. Melatonin is not a conventional hormone as it can functions via receptor-dependent and receptor-independent manner by binding with nuclear binding sites or serine/threonine (Ser/Thr) kinases like death-associated protein kinase 1 [27-30]. Additionally, melatonin is amphiphilic, this character of melatonin provides it the ability to diffuse and cross all morpho-physiological barriers, enter all the cells, and in- 
fluence numerous function [31-37]. Owing to the virtual omnipresence, cytoprotective, and chronobiotic abilities along with biocompatibility, melatonin is considered as a powerful therapeutic drug for the treatment of various diseases (Figure 1). As melatonin can cross-blood brain barrier and enter any cell and modulate many functions, melatonin is used as a drug for many degenerative neural damages such as Alzheimer's disease (AD), Parkinson's disease (PD), Huntington's disease (HD) or amyotrophic lateral sclerosis, etc.

Progressive degradation of the neurons in the sensory, motor, or cognitive system is the primary characteristic of neurodegenerative disorders leading to diseases such as $\mathrm{AD}$, dementia, $\mathrm{PD}$, or HD. Neurodegeneration in all these disorders follows similar molecular processes like oxidation mediated degeneration, impairment of mitochondria, excitotoxicity, and inflammation [38,39]. Even though the regular intake of drugs with antioxidants, antiinflammatory, and antiapoptotic activity has been proposed for management or treatment of neural damage, however, their effectiveness has been questioned and most of them are under the primary stages of drug development (Table 1) [40-69]. In this context, melatonin simultaneously offers antioxidant, anti-inflammatory, and antiapoptotic activity. Therefore, melatonin is considered as a promising target for the treatment or management of neurodegenerative diseases. The focus of this article is on the role of melatonin in neural tissues. We will discuss the role of melatonin in the central nervous system (CNS) and peripheral nervous system (PNS). Following that, an overview of functions of melatonin in the endoplasmic reticulum (ER) and mitochondria in neural tissues will be addressed. Finally, we will review the role of melatonin on apoptotic cell death and autophagy and its associated pathway.

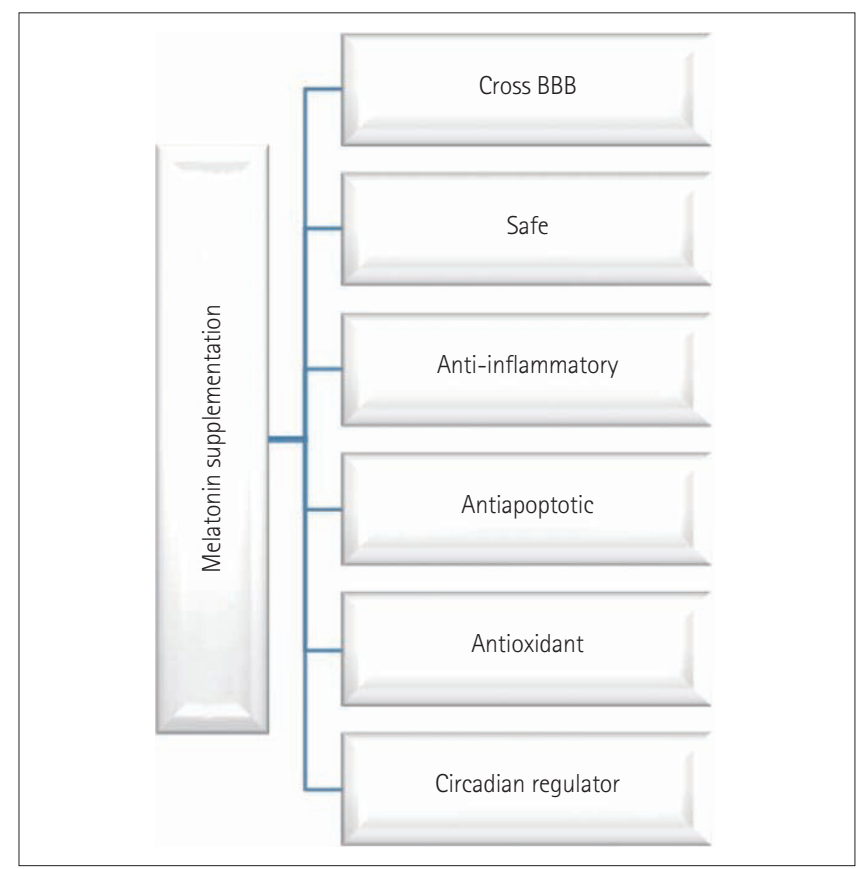

Figure 1. Possible effects of melatonin supplementation. BBB: blood-brain barrier.

\section{THE EFFECTS OF MELATONIN ON THE CENTRAL AND PERIPHERAL NERVOUS SYSTEM}

Neural tissues, located in both the CNS and PNS, exhibit degenerative changes with age. Even though the formation of new myelin has been reported to occur, myelin sheaths with dense cytoplasm and balloons have also been observed [70]. As these occurrences affect functions such as conduction velocity and normal timing in the neural circuit, structural changes of myelin lead to cognitive decline with age [70]. Furthermore, neural degeneration in the PNS is induced by detrimental stimuli or injury $[71,72]$. Peripheral nerve injury typically results in the loss of sensory, motor, and autonomic functions either partially or totally. Damage induced by peripheral nerve injury occurs from the original lesioned nerves to the denervated segments of the body due to the discontinuity of axons, degeneration of nerve fibers, and eventual death of injured neurons [73]. Previous studies have found increased oxidative stress in the neural tissues of subjects from an $\mathrm{AD}$ animal model [74-77]. Reactive oxygen species (ROS) are primarily generated by the Fenton reaction, which induces intracellular mitogen-activated protein kinase (MAPK) activation, $\mathrm{Ca}^{2+}$ dyshomeostasis, and apoptosis [78,79]. Interestingly, the oxidative condition is correlated with the clinical symptoms of AD such as memory deficits and cognitive impairments in both rodents and humans $[80,81]$. Similarly, sciatic nerve crush injury is a well-established rodent model due to its ability to impair axonal connectivity [82]. There is an up-regulation of oxidative stress-induced lipid peroxidation as well as a down-regulation of glutathione (GSH) and catalase in the sciatic nerve constriction model [83]. Cumulatively, ROS generation is induced when nerves are injured in both CNS and PNS. Therefore, researchers have focused on potent antioxidant substances that inhibit the progression of AD. Numerous studies have demonstrated the antioxidant effects of natural products or chemicals in vitro and in vivo and have shown that decreased oxidative stress improves neurological function in rodents with $\mathrm{A} \beta$-induced $\mathrm{AD}$ and humans [80,84-87]. Olcese et al. [88] observed a beneficial effect of melatonin regarding the prevention of cognitive deficits and the suppression of oxidative stress-induced neurodegeneration via the up-regulation of antioxidant enzymes [e.g., superoxide dismutase (SOD-1), glutathione peroxidase, and catalase] and enhancement of the anti-inflammatory response by down-regulation of tumor necrosis factor-alpha (TNFa). Recently, the regulatory functions of melatonin, which are involved in its neuroprotective action against $A \beta$-induced neurotoxicity, were identified. It was shown that the neuroprotective effects under $A \beta$ induced toxicity are mediated by the ROS scavenging and the protection of astrocytes from mitochondrial depolarization [89]. In addition to its antioxidant properties, melatonin produces anti-inflammatory and antiapoptotic activity and increases neurotrophin production during $\mathrm{AD}$ progression both in vitro and in vivo [90-94]. These studies performed with $\mathrm{AD}$ patients have found a significant association between melatonin administration and im- 
Table 1. List of drugs for neurodegenerative diseases with the mode of action/target including antioxidant or anti-inflammatory or antiapoptotic activity

\begin{tabular}{|c|c|c|c|c|}
\hline Drug & Company & $\begin{array}{l}\text { Highest } \\
\text { dev. status }\end{array}$ & Indication & Mode of action/drug effect \\
\hline AM-36 [40] & AMRAD Corp., Ltd. & Discovery & $\begin{array}{l}\text { Cerebrovascular ischemia; AD; } \\
\text { spinal cord injury }\end{array}$ & $\begin{array}{l}\text { Antioxidant agent; sodium channel } \\
\text { blocker; }\end{array}$ \\
\hline Dehydroascorbic acid [41] & $\begin{array}{l}\text { Memorial Sloan Kettering } \\
\text { Cancer Center }\end{array}$ & Discovery & $\begin{array}{l}\mathrm{AD} ; \mathrm{ND} ; \mathrm{PD} \text {; cerebrovascular } \\
\text { ischemia }\end{array}$ & Antioxidant agent \\
\hline Imidazolyl nitrones $[42,43]$ & Servier & Discovery & Nervous system injury; ND & Neuroprotectant; antioxidant agent \\
\hline $\begin{array}{l}\text { Mitoquinone/ } \\
\text { mitoquinol redox } \\
\text { mixture [44] }\end{array}$ & $\begin{array}{l}\text { Antipodean } \\
\text { Pharmaceuticals, Inc. }\end{array}$ & Phase 2 & PD; sunburn; liver disease & $\begin{array}{l}\text { Neuroprotectant; antiparkinsonian; } \\
\text { antioxidant agent; anti-inflammatory }\end{array}$ \\
\hline NAPVSIPQ [45] & National Institutes of Health & Discovery & ND & Antioxidant agent; neuroprotectant \\
\hline NOX-700 [46] & Medinox, Inc. & $\begin{array}{l}\text { Phase } 1 \\
\text { clinical }\end{array}$ & ND & Antioxidant agent \\
\hline PAN-811 [47] & Panacea Pharmaceuticals, Inc. & Discovery & $\mathrm{AD}$ & Antioxidant agent; neuroprotectant \\
\hline $\begin{array}{l}\text { Lipid soluble antioxidants } \\
\text { [48] }\end{array}$ & OXIS International, Inc. & Discovery & $\begin{array}{l}\mathrm{AD} ; \mathrm{PD} \text {; cardiovascular disease; } \\
\text { diabetes mellitus }\end{array}$ & $\begin{array}{l}\text { Antioxidant agent; antiparkinsonian; } \\
\text { neuroprotectant; cardioprotectant }\end{array}$ \\
\hline S-33113-1 [48] & Servier & Discovery & ND; cerebrovascular ischemia & Antioxidant agent; neuroprotectant \\
\hline QR-333 [49] & Quigley Pharma, Inc. & Phase 2 & Diabetic neuropathy & $\begin{array}{l}\text { Antioxidant agent; aldose reductase } \\
\text { inhibitor/neuroprotectant }\end{array}$ \\
\hline AAD-2004 [50] & $\begin{array}{l}\text { Neurotech Pharmaceuticals } \\
\text { Co., Ltd./AmKor Pharma, Inc. }\end{array}$ & Discovery & $\begin{array}{l}\mathrm{AD} \text {; dementia; beta amyloid } \\
\text { antagonist }\end{array}$ & $\begin{array}{l}\text { Anti-inflammatory; antioxidant agent; } \\
\text { neuroprotectant; antiparkinsonian }\end{array}$ \\
\hline AEOL-10150 [51] & Aeolus Pharmaceuticals, Inc. & Phase 1 & $\begin{array}{l}\text { Motor neurone disease; lung } \\
\text { inflammation; poison } \\
\text { intoxication }\end{array}$ & $\begin{array}{l}\text { Anti-inflammatory; antioxidant; } \\
\text { angiogenesis inhibitor; } \\
\text { neuroprotectant; radioprotectant }\end{array}$ \\
\hline AO-1-530 [52] & Antoxis, Ltd. & Discovery & Cerebrovascular ischemia & $\begin{array}{l}\text { Antioxidant agent; free radical } \\
\text { scavenger; neuroprotectant }\end{array}$ \\
\hline Catalytic antioxidants [53] & Aeolus Pharmaceuticals, Inc. & Discovery & $\begin{array}{l}\text { Chronic bronchitis; motor } \\
\text { neuron disease; PD; asthma; } \\
\text { cerebrovascular ischemia; } \\
\text { cancer; epilepsy }\end{array}$ & $\begin{array}{l}\text { Antioxidant agent; anticancer; } \\
\text { radioprotectant; anticonvulsant agent }\end{array}$ \\
\hline VX-799 $[54,55]$ & $\begin{array}{l}\text { Serono; Vertex } \\
\text { Pharmaceuticals, Inc. }\end{array}$ & Discovery & $\begin{array}{l}\text { ND; cardiovascular disease; } \\
\text { cerebral infarction; } \\
\text { cerebrovascular ischemia }\end{array}$ & $\begin{array}{l}\text { Apoptosis inhibitor; neuroprotectant; } \\
\text { vasoprotectant; anti-inflammatory }\end{array}$ \\
\hline ReN-1820 [56] & ReNeuron (UK), Ltd. & Discovery & $\begin{array}{l}\text { AD; inflammation; pain; ND; } \\
\text { dementia }\end{array}$ & $\begin{array}{l}\text { NGF antagonist; nootropic agent; } \\
\text { analgesic; anti-inflammatory }\end{array}$ \\
\hline AEG-3482 series [ 57$]$ & Aegera Therapeutics, Inc. & Discovery & $\begin{array}{l}\text { Multiple sclerosis; } \\
\text { cerebrovascular ischemia; } \\
\text { cancer }\end{array}$ & Apoptosis inhibitors; neuroprotectant \\
\hline DP-109 [58] & D-Pharm, Ltd. & Discovery & $\mathrm{ND}$ & $\begin{array}{l}\text { Chelating agent; apoptosis modulator; } \\
\text { neuroprotectant }\end{array}$ \\
\hline DP-b99 $[59,60]$ & $\begin{array}{l}\text { D-Pharm, Ltd./Yungjin } \\
\text { Pharmaceutical Co., Ltd./ } \\
\text { Wanbang Biopharma }\end{array}$ & $\begin{array}{l}\text { Phase } 3 \\
\text { (phase 2) }\end{array}$ & $\begin{array}{l}\text { Cerebrovascular ischemia; brain } \\
\text { injury; ND }\end{array}$ & $\begin{array}{l}\text { Anti-inflammatory; antioxidant agent; } \\
\text { chelating agent; apoptosis modulator; } \\
\text { neuroprotectant }\end{array}$ \\
\hline $\begin{array}{l}\text { Huperzine-A } \\
\text { (transdermal patch, } \\
\text { Alzheimer's disease) [61] }\end{array}$ & $\begin{array}{l}\text { Neuro-Hitech, Inc./Xel } \\
\text { Herbaceuticals, Inc. }\end{array}$ & Phase 1 & $\begin{array}{l}\text { AD; acetylcholinesterase } \\
\text { inhibitor; beta-amyloid } \\
\text { modulator }\end{array}$ & $\begin{array}{l}\text { Antioxidant agent; NMDA receptor; } \\
\text { antagonist; neuroprotectant }\end{array}$ \\
\hline Dykellic acid $[62,63]$ & $\begin{array}{l}\text { Korea Research Institute of } \\
\text { Bioscience and } \\
\text { Biotechnology }\end{array}$ & Discovery & Immune disorder; ND; cancer & $\begin{array}{l}\text { Apoptosis inhibitor; anticancer; } \\
\text { antiapoptotic }\end{array}$ \\
\hline IAP [64] & Aegera Therapeutics, Inc. & Discovery & $\begin{array}{l}\text { PD; multiple sclerosis, } \\
\text { cerebrovascular ischemia }\end{array}$ & Antiapoptotic; neuroprotectant \\
\hline IDN-6556 [65,66] & Idun Pharmaceuticals, Inc. & Discovery & ND & $\begin{array}{l}\text { Apoptosis inhibitor; } \\
\text { anti-inflammatory }\end{array}$ \\
\hline Rasagiline $[67,68]$ & $\begin{array}{l}\text { Teva Pharmaceutical } \\
\text { Industries, Ltd. }\end{array}$ & $\begin{array}{l}\text { Phase } 3 \\
\text { clinical }\end{array}$ & $\mathrm{AD} ; \mathrm{ND} ; \mathrm{PD}$ & $\begin{array}{l}\text { Apoptosis inhibitor; MAO B inhibitor; } \\
\text { antiparkinsonian }\end{array}$ \\
\hline SPM-914 [42,69] & $\begin{array}{l}\text { Alviva Biopharmaceuticals, } \\
\text { Inc./Schwarz }\end{array}$ & Discovery & PD; HD; motor neuron disease & $\begin{array}{l}\text { Neurodegenerative disease; Parkinson's } \\
\text { disease; apoptosis inhibitor }\end{array}$ \\
\hline
\end{tabular}


proved sleep patterns [95]. Therefore, it may be beneficial to focus not only on the role of melatonin during primary neuropathological progression but also on secondary $\mathrm{AD}$-induced problems such as the interruption of sleep. Shokouhi et al. [96] found that melatonin reduces lipid peroxidation in sciatic nerve-injured animals in a dose-dependent manner. Also, in the sciatic nerve transection model, treatment with melatonin reduces motor neuron loss in the lumbar spinal cord, stimulates SOD1/2 production, and aids in the recovery of action potentials in the crushed sciatic nerve both in vitro and in vivo [97,98]. Melatonin also inhibits collagen deposition in the neuroma formed by the injured sciatic nerve, whereas melatonin depletion, as induced by pinealectomy, increases collagen content [99]. Moreover, compared to control, melatonin treatment elevates the sciatic functional index, improves conduction velocity, and attenuates latency values as measured by in vivo electromyography; with no difference between low $(5 \mathrm{mg} / \mathrm{kg})$ and high $(20 \mathrm{mg} / \mathrm{kg})$ doses [100]. Therefore, it can be concluded that melatonin can stimulate neural regeneration through a decrease of pro-oxidants and the up-regulation of neurotrophic factors.

\section{THE EFFECTS OF MELATONIN ON ENDOPLASMIC RETICULUM IN NEURAL TISSUES}

The ER has important functions, which include the synthesis, folding, and translational modification of proteins. ER stress occurs when ER homeostasis is abnormally regulated and results in the activation of unfolded protein responses (UPR) to reduce ER stress [101]. UPRs are initiated by three ER membrane-associated proteins, PRKR-like endoplasmic reticulum kinase (PERK), inositol requiring enzyme 1 (IRE), and activating transcription factor 6 (ATF6a), which up-regulate the expression of ER chaperones such as binding immunoglobulin protein/glucose-regulated protein 78 and 94 (Bip/Grp78 and Grp94) [102]. The accumulation of misfolded proteins, which activate UPRs, is a common feature of many neurodegenerative diseases, including AD, PD, and HD [103-107]. These studies indicate the importance of ER homeostasis and its role in the degenerative changes of neural tissues.

Interestingly, there are $\mathrm{AD}$-like phenotypes, including spatial memory impairment, tau hyperphosphorylation, and the up-regulation of ER chaperones (e.g., BiP/GRP78, CHOP/GADD153), in illumination-induced melatonin-deprived rats [108]. Brain damage induced by Arsenite exposure increases ATF4, C/EBP homologous protein (CHOP), sXBP1, and pro-caspase 12 levels whereas, melatonin represses the expressions of these factors and leads to an inhibition of apoptosis [109]. In another report, Kang et al. [110] found that treadmill exercise suppresses ER stress responses via the inhibition of PERK, eukaryotic translation initiation factor $2 a$ (eIF2 $\alpha$ ), ATF6 $\alpha$, sXBP1, and CHOP activation, reduces the deposition of $\mathrm{A} \beta$-peptide ${ }_{42}$, and prevents memory dysfunction in aged PS2 mutant mice. Recently, it has been shown that in cerebral ischemia mice, melatonin operates with the same pathway. It not only decreases the phosphorylation of PERK and eIF2 $\alpha$ but also sup- presses the expression of ATF4 and CHOP. Simultaneously, the level of cytochrome $\mathrm{c}$ (Cyto c) was reduced and the expression of caspase-3 was down-regulated (Figure 2) [111]. Based on the aforementioned evidence, it can be concluded that melatonin contributes to the amelioration of neural degeneration through ER-associated signaling pathways.

\section{THE EFFECT OF MELATONIN ON MITOCHONDRIA IN NEURAL TISSUES}

A growing amount of evidence indicates that mitochondria play a pivotal role in the pathophysiology of various diseases [112]. Mitochondrial damage can occur through the impairment of electron flux via the electron transport chain, which results in electron leakage and generates oxidation in a self-stimulatory feedback loop. Recent studies have shown that melatonin can attenuate the generation of ROS and reactive nitrogen species (RNS) from mitochondria under several detrimental conditions and protect against the oxidative, nitrosative, and nitrative damage of electron transport chain proteins. Additionally, melatonin prevents lipid peroxidation in the inner membrane of mitochondria, which leads to electron flux and energy efficiency [113-115]. To understand the mechanisms underlying these findings, the site of radical generation in mitochondria and the causes of mitochondrial dysfunction should be addressed.

Melatonin has been shown to negatively modulate free radicals, and the regulation of inducible nitric oxide (NO) synthase (iNOS) and neuronal NO synthase (nNOS) [116]. Inflammatory and stressassociated signaling primarily up-regulates iNOS in astrocytes, microglia, and macrophages. In contrast, excitation dependent $\mathrm{Ca}^{2+}$ influx affects the regulation of nNOS, especially in glutamatergic

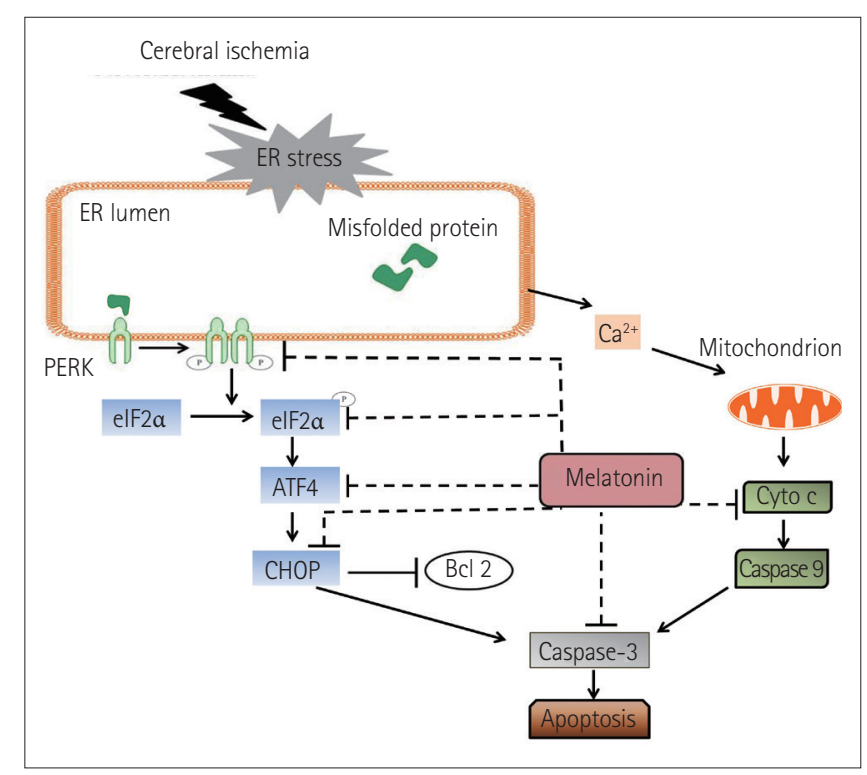

Figure 2. The mechanisms of melatonin protected neurons against endoplasmic reticulum (ER)-induced apoptosis after cerebral ischemia. Reprinted from Lin et al. Int J Mol Med 2018;42:182192 [111], according to the Creative Commons License (CC-BYNC-ND). 
neurons. Although a reasonable level of increase in NO radicals is likely to be suitable for mitochondrial function, significantly high levels often induce severe impairments in the electron transfer chain (ETC) [117]. The adverse effect of the NO radical and its non-enzymatically formed metabolites are responsible for the impairment of ETC, especially under detrimental conditions such as chronic inflammation [118]. Melatonin has been reported to have a potent influence on carbonate radicals and to be a scavenger of hydroxyl radicals [119-122]. Furthermore, the nitrosation of armates has been observed in the nitrosodioxyl radical, an analog of peroxynitrite that could be formed by electron abstraction from peroxynitrite; however, this has not been studied in electron transport chain proteins. If melatonin is administrated at high pharmacological doses, it might react with products mostly originating from these peroxynitrite. Nonetheless, at low pharmacological concentrations, the potential to inhibit the up-regulated iNOS or nNOS exists. This action of melatonin can break the malicious cycle of high NO radicals, which leads to a blockade of the electron transport chain in various ways, including by combining with the superoxide anion to produce strongly reactive factors that impair respirasomes, interrupt electron flux, and induce electron backflow and leakage.

Mitochondrion-dependent apoptosis, also termed the intrinsic apoptotic pathway, is one of the major apoptotic signaling pathways [123]. Mitochondrion-dependent apoptosis causes mitochondrial membrane permeabilization (MMP), caused by the opening of mitochondrial permeability transition pore (mPTP), which refers to the swelling and depolarization of mitochondria evident upon the development of a cytosolic calcium burst or when oxidative stress is in play [124-126]. MMP is thought to block ATP synthesis by oxidative phosphorylation in mitochondria and to stimulate ATP hydrolysis [125]. Melatonin levels have been reported to be higher inside the mitochondria than in the plasma [127]. Moreover, melatonin is thought to contribute to mitochondrial homeostasis $[128,129]$ by 1$)$ facilitating hydrogen peroxide $\left(\mathrm{H}_{2} \mathrm{O}_{2}\right)$ scavenging $\left(\mathrm{H}_{2} \mathrm{O}_{2}\right.$ is one of the most important ROS produced by mitochondria) and 2) improving mitochondrial function (increasing ATP synthesis, reducing ROS production, and protecting against abnormal decreases in mitochondrial membrane potential which could, in turn, trigger MMP) [130,131]. The release of Cyto c from mitochondria into the cytosol can initiate mitochondrion-dependent apoptosis via downstream activation of cell death pathways [132]. Melatonin not only blocks mPTP opening but also the MPTP-dependent release of Cyto $c$, whose release would inhibit caspase 3 , triggering apoptotic cell death [133]. Some authors consider that ROS generation, caused by a decrease in mitochondrial membrane potential, may trigger mitochondrion-dependent apoptosis $[128,134]$. Similarly, the opening of mPTP under oxidative stress may play a role in the induction of apoptosis [128]. Melatonin maintains mitochondrial membrane permeability by preventing lipid peroxidation and also controls mitochondrial $\mathrm{H}_{2} \mathrm{O}_{2}$ levels, both under normal conditions and when oxidative stress is in play $[11,128]$. Additionally, melatonin seems to inhibit the ROS-induced increase in calcium levels [135]. Oxida- tive stress is a powerful regulator of the sensitivity of mPTPs to calcium ions. Thus, melatonin indirectly blocks the opening of the $\mathrm{mPTPs}$ and the induction of apoptotic cascades via the release of mitochondrial Cyto $c$ and activation of caspase 3 [11].

Endogenous levels or exogenous administration of melatonin offers protection to injured cells from several cell death forms like, mPTP-driven cell death, necroptosis, apoptosis, and autophagy. Melatonin is highly permeable in a variety of cells organelles too, and its protective effects can be mediated through both melatonin receptor-dependent or independent manner. Inside the cytoplasm, melatonin inhibits the receptor-interacting serine/threonine-protein kinase 3 (Ripk3) mechanisms, up-regulation of dynamin-related protein (Drp1), and Bax-dependent Cyto $\mathrm{c}$ release caused by external insults, leading to pro-survival signals. Mitochondrial melatonin offers protective roles by interaction with peptide transporter 1 (PEPT1/2) and Glucose transporter (GLUT), which are considered as the novel melatonin receptors in the mitochondrion (Figure 3) [11].

\section{THE EFFECTS OF MELATONIN ON PROGRAMMED CELL DEATH IN NEURAL TISSUES}

Programmed cell death (PCD), refers to cell death mediated by intracellular programs. Three forms of PCD are known: apoptosis, autophagy, and programmed necrosis, apoptosis is most well understood [136]. PCD is important during neural development as it plays a central role in rendering the neuronal environment by regulating both the numbers and types of cells in the CNS $[137,138]$. Apoptosis is critical in regulating neuronal cell death, both during neural development and in various neurodegenerative diseases. Lower expression of apoptotic protease activating factor 1 (Apaf1) expression, can lead to abnormal brain enlargement because of apoptosis deregulation and may cause prenatal fatality in experimental animals $[139,140]$. Some studies have shown that excessive apoptotic cell death attributed to the lack of the antiapoptotic protein Bcl-x may cause neuronal immaturity in the developing brain and spinal cord leading to embryonic death [141]. Moreover, it is also shown that primary spinal cord injury is generally followed by apoptosis, inflammation, free-radical-induced lipid peroxidation, and vascular damage [142,143].

A considerable amount of literature has shown that apoptotic cell death can be affected by melatonin. Neural injuries elicit excitotoxicity, alteration of calcium ion homeostasis, increased nitric oxide synthesis, and finally, apoptosis $[30,144]$. Melatonin seems to protect neuronal cells from apoptotic cell death-mediated neurotoxicity by regulating the expression of proteins by enhancement of the interaction between $\mathrm{pBad}$ and 14-3-3, inhibiting activation of apoptosis cascades [145,146]. In subarachnoid hemorrhage (SAH), exogenous melatonin can reduce $\mathrm{SAH}$-induced early brain injury by inhibiting excessive neuronal apoptosis and autophagy probably by the reactive oxygen species-mammalian sterile 20-like kinase 1 (ROS-MST1) pathway (Figure 4) [147]. 
Autophagy, another type of PCD, is critical as it balances the formation and degradation of proteins, therefore, autophagy is not only a cell death pathway, but it can also promote cell survival $[138,148]$. Recently, autophagy has been considered as a pro-survival signaling pathway as it has shown a protective effect against necrotic cell death in neonatal rats subjected to brain damage by hypoxia-ischemia [149]. Conversely, deleterious aspects of autophagy have also been reported. After middle cerebral artery occlusion, the size of infarct was reduced upon injection of an inhibitor of autophagy [150]. Additionally, both brain edema and total infarct volume were also reduced by such an autophagy inhibitor [151]. After traumatic brain injury, autophagy is thought to induce

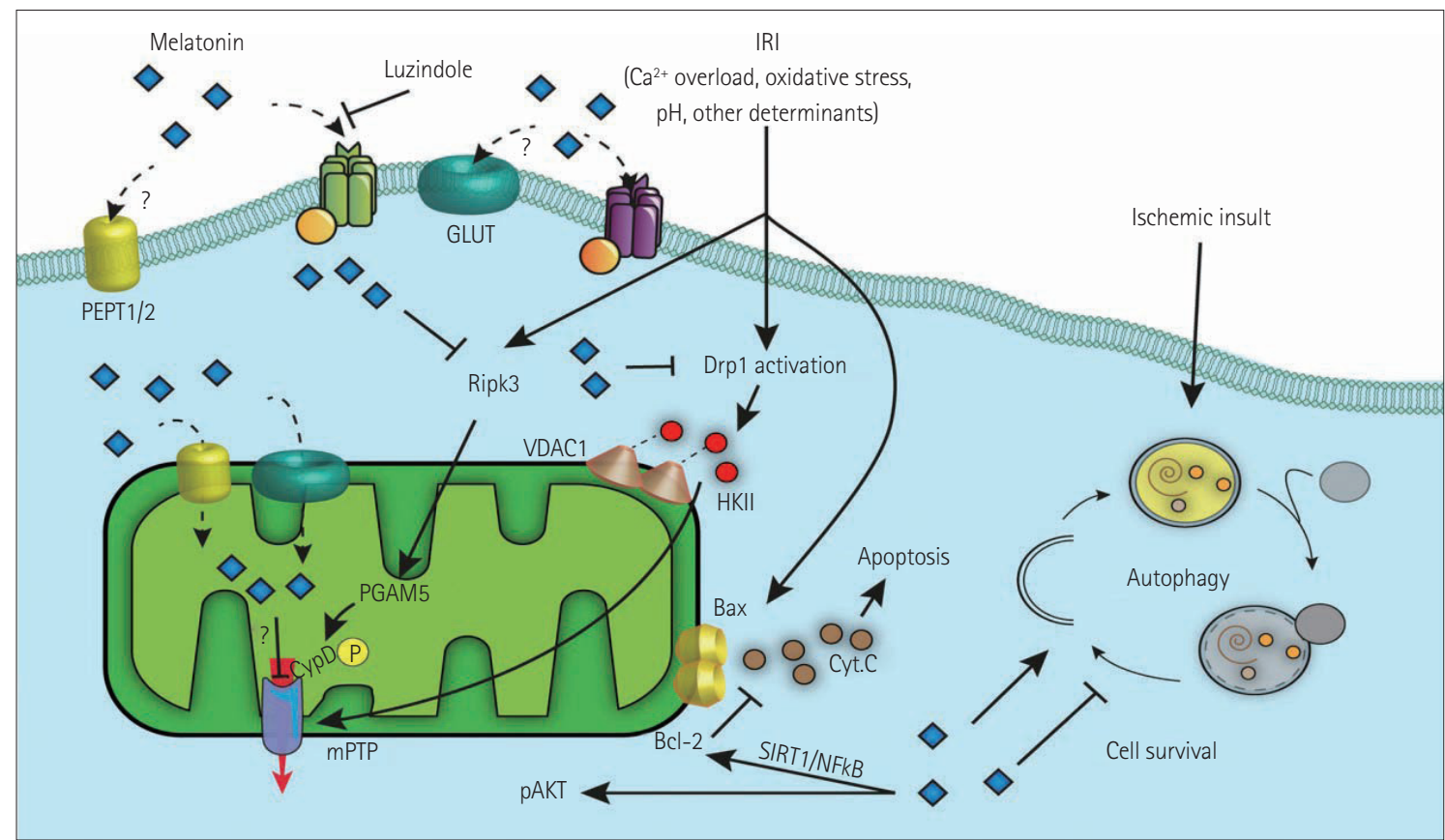

Figure 3. Antiapoptotic mechanisms operated by melatonin. Reprinted from Tarocco et al. Cell Death Dis 2019;10:317 [11], according to the Creative Commons License (CC-BY).
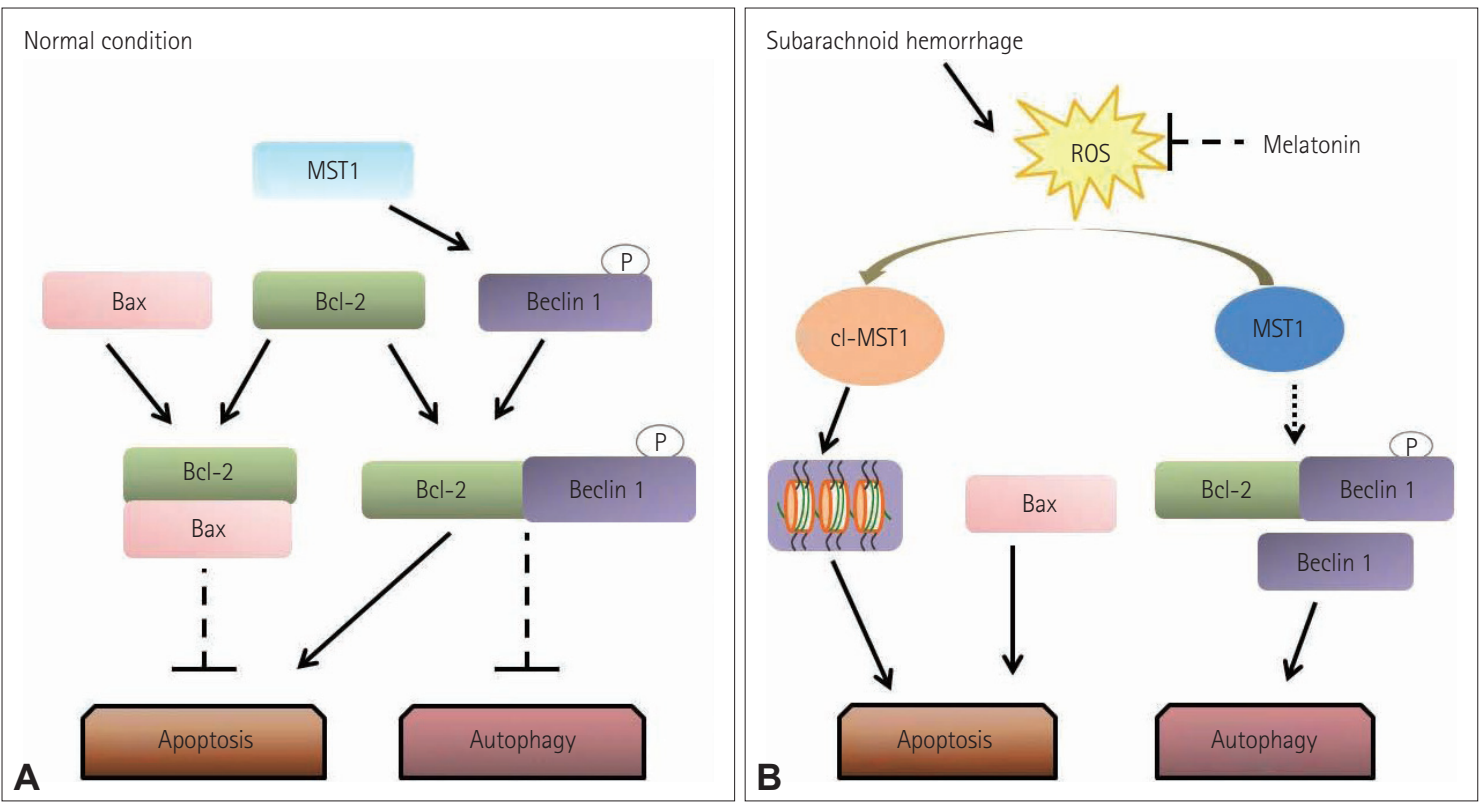

Figure 4. Proposed role of melatonin in regulating the balance between apoptosis and autophagy. (A) In normal situations, Bcl-2 binds with Bax and inhibiting the Bax-induced channel formation which is permeable to cytochrome $\mathrm{c}$ to activate caspase-3 dependent apoptosis. Additionally, MST1 present in the cell helps in cell survival by phosphorylating Beclin 1 which prevents the synthesis of Beclin 1-Atg14L-Vps34, which can inhibit autophagy and activate apoptosis. (B) In subarachnoid hemorrhage stress, the increased brain reactive oxygen species (ROS) content activates the cleavage of MST1 to produce cl-MST1, which is transferred into the nucleus and phosphorylates several histones, inducing neuronal cell apoptosis. Besides, subarachnoid hemorrhage reduces the level of Bcl-2 protein, displacing Bax from Bcl-2 to enhance apoptosis. In the meantime, both the down-regulation of Beclin 1 phosphorylation by MST1 and the low expression of $\mathrm{Bcl}-2$ cause the dissociation of the Bcl-2/Beclin 1 complex, increasing the cell autophagy. Reprinted form Shi et al. Front Mol Neurosci 2018;11:93 [147], according to the Creative Commons License (CC-BY). 
cell death. Consequently, the effect of autophagy on the fate of cells remains ambiguous.

It has recently been shown that melatonin regulates autophagy. Park et al. [152] have shown melatonin induced rapid activation of autophagy after spinal cord injury. Inversely, Guo et al. [153] suggested that inhibition of autophagy could eliminate any beneficial role played by melatonin. The same study also reported the neuroprotective role of autophagy was augmented by melatonin, indicating that activation of autophagy might be protective [153]. To explain the Janus-faced nature of autophagy, it was suggested that melatonin-mediated autophagy induces autophagic cell death only if the extent of cellular damage exceeds a certain level, whereas it promotes cell survival if the damage is less extensive [153]. Conversely, other researchers have found that melatonin can be anti-autophagic. It has been proposed that melatonin plays a protective role after brain injury by activating the Class I Phosphatidylinositol 3-kinase/protein kinase B (PI3K/Akt) signaling pathway, which negatively regulates autophagy [154]. Similarly, it has been suggested that melatonin exerts beneficial effects after brain injury by activating the rapamycin kinase pathway (mTOR/p70S6 kinase), the downstream target of Akt [30]. Activation of autophagy by inhibiting apoptosis can be beneficial in several circumstances. Such activation improves locomotor function in animals with spinal cord injuries [155]. A tumor-suppressing effect was also evident [74], as was the melatonin-induced improvement of cell survival in animal models of SAH [156,157]. Interestingly, the simultaneous down-regulation of apoptosis and autophagy may exert protective effects in animal models of brain injury [158]. Future studies should explore the details of the complex interactions between the mechanisms of PCD and neural injury.

\section{SUMMARY AND CONCLUSION}

Oxidative stress and inflammatory response leading to different modes of PCD have been involved in the pathogenesis of various neurodegenerative diseases such as $\mathrm{AD}, \mathrm{PD}, \mathrm{HD}$ and other neurological conditions including stroke, $\mathrm{SAH}, \mathrm{SCI}$, and brain trauma. Generally, high oxygen utilization and low anti-antioxidant levels are the main reasons for enhanced oxidative stress in damaged neural tissue and aged individuals. Melatonin is an excellent drug both in vivo and in vitro in neurodegenerative diseases. Melatonin has been shown to reduce derogatory neuropathological changes not only by ROS and RNS scavenging but also by decreasing the phosphorylation of PERK/eIF2 $\alpha$ and suppressing ATF4/CHOP which down-regulates the caspase- 3 mediated apoptosis. Furthermore, melatonin may also inhibit excessive neuronal apoptosis and autophagy, possibly by the ROS-MST1 pathway. The fact that melatonin easily crosses the blood-brain barrier, enters any cell, acts with and without the receptor, along with its high tolerance and biocompatibility even at the highest dosages, represents the significance of melatonin in treatment or management of neural damage. However, the number of randomized controlled studies testing the efficacy of melatonin on neural damage and neurodegenerative disorders is limited, and the experiment quality is often unsatisfactory. Lack of potential biomarkers to study the changes in neural damages after drug treatment makes these studies more challenging. There is a need for more clinical trials to study the protective role of melatonin. Moreover, the search for reliable biomarkers to study the post-drug administration changes in neural damage should be expedited.

\section{Acknowledgments}

The authors would like to acknowledge the invaluable support and critical comments of members in 'Biological Clock \& Aging Control' laboratory. This work was supported by a grant from the National Research Foundation (NRF-2020R1A2C201215511), Korea. Jeonghyun Choi is supported by a post-doctoral fellowship from National Research Foundation (NRF-2019R1A6A3A01091422), Korea.

\section{Conflicts of Interest}

The authors have no potential conflicts of interest to disclose.

\section{Author Contributions}

Conceptualization: Yonggeun Hong, Yunkyung Hong, Zeeshan Ahmad Khan. Data curation: Zeeshan Ahmad Khan, Yunkyung Hong, Jeonghyun Choi, Youngjeon Lee, Yunho Jin. Project administration: Yonggeun Hong. Resources: Yonggeun Hong. Supervision: Yonggeun Hong. Writing-original draft: Zeeshan Ahmad Khan, Yunkyung Hong, Yonggeun Hong. Writing-review \& editing: Yonggeun Hong, Zeeshan Ahmad Khan.

\section{ORCID iDs}

Yonggeun Hong (1)

https://orcid.org/0000-0003-1288-0546

Zeeshan Ahmad Khan

https://orcid.org/0000-0002-0737-0253

\section{REFERENCES}

1. Khan ZA. Photo period and ovarian physiology a chronobiological approach in zebra fish (Danio rerio) [dissertation]. Gauhati University, 2017.

2. Khan ZA, Labala RK, Yumnamcha T, Devi SD, Mondal G, Sanjita Devi H, et al. Artificial Light at Night (ALAN), an alarm to ovarian physiology: a study of possible chronodisruption on zebrafish (Danio rerio). Sci Total Environ 2018;628-629:1407-1421.

3. Khan ZA, Yumnamcha T, Rajiv C, Sanjita Devi H, Mondal G, Devi SD, et al. Melatonin biosynthesizing enzyme genes and clock genes in ovary and whole brain of zebrafish (Danio rerio): Differential expression and a possible interplay. Gen Comp Endocrinol 2016;233:16-31.

4. Rajiv C, Sanjita Devi H, Mondal G, Dharmajyoti Devi S, Khan ZA, Yumnamcha $\mathrm{T}$, et al. Cloning, phylogenetic analysis and tissue distribution of melatonin bio-synthesizing enzyme genes (Tph1, Aanat1, Aanat2 and Hiomt) in a tropical carp, Catla catla. Biol Rhythm Res 2017;48:371-386.

5. Kim Y, Lee SJ, Park CS, Kim BJ, Lee CS, Cha B, et al. The mediating effect of eveningness on the indirect relationships between shorter sleep duration, inattention, depression with smartphone addiction tendency. Chronobiol Med 2020;2:32-40.

6. Kripke DF. Delayed circadian rhythms and pars tuberalis dysfunction in mood disorders. Chronobiol Med 2020;2:1-2.

7. Geoffroy PA. The light of hope in antidepressant strategies. Chronobiol 
Med 2020;2:57-60.

8. Onen SH, Onen F. Circadian sleep disruption and cancer risk. Chronobiol Med 2019;1:137-143.

9. Cho $\mathrm{CH}$, Lee $\mathrm{Y}$. The chronobiologic-based practical approach to shift work. Chronobiol Med 2019;1:103-106.

10. Cajochen C, Kräuchi K, Wirz-Justice A. Role of melatonin in the regulation of human circadian rhythms and sleep. J Neuroendocrinol 2003;15: 432-437.

11. Tarocco A, Caroccia N, Morciano G, Wieckowski MR, Ancora G, Garani $\mathrm{G}$, et al. Melatonin as a master regulator of cell death and inflammation: molecular mechanisms and clinical implications for newborn care. Cell Death Dis 2019;10:317.

12. Binkley S, Mosher K, Rubin F, White B. Xenopus tadpole melanophores are controlled by dark and light and melatonin without influence of time of day. J Pineal Res 1988;5:87-97.

13. Ekstrzm P, Meissl H. The pineal organ of teleost fishes. Rev Fish Biol Fisher 1997;7:199-284.

14. Falcón J. Cellular circadian clocks in the pineal. Prog Neurobiol 1999;58: 121-162.

15. Falcón J, Besseau L, Fuentès M, Sauzet S, Magnanou E, Boeuf G. Structural and functional evolution of the pineal melatonin system in vertebrates. Ann N Y Acad Sci 2009;1163:101-111.

16. Falcón J, Besseau L, Sauzet S, Boeuf G. Melatonin effects on the hypothalamo-pituitary axis in fish. Trends Endocrinol Metab 2007;18:81-88.

17. Falcón J, Migaud H, Muñoz-Cueto JA, Carrillo M. Current knowledge on the melatonin system in teleost fish. Gen Comp Endocrinol 2010;165:469482.

18. Gooley JJ, Lu J, Chou TC, Scammell TE, Saper CB. Melanopsin in cells of origin of the retinohypothalamic tract. Nat Neurosci 2001;4:1165.

19. Zhao D, Yu Y, Shen Y, Liu Q, Zhao Z, Sharma R, et al. Melatonin synthesis and function: evolutionary history in animals and plants. Front Endocrinol (Lausanne) 2019;10:249.

20. Chen CQ, Fichna J, Bashashati M, Li YY, Storr M. Distribution, function and physiological role of melatonin in the lower gut. World J Gastroenterol 2011;17:3888-3898.

21. Gonzalez-Arto M, Hamilton TR, Gallego M, Gaspar-Torrubia E, Aguilar D, Serrano-Blesa E, et al. Evidence of melatonin synthesis in the ram reproductive tract. Andrology 2016;4:163-171.

22. Scher J, Wankiewicz E, Brown GM, Fujieda H. MT(1) melatonin receptor in the human retina: expression and localization. Invest Ophthalmol Vis Sci 2002;43:889-897.

23. Brennan R, Jan JE, Lyons CJ. Light, dark, and melatonin: emerging evidence for the importance of melatonin in ocular physiology. Eye (Lond) 2007;21:901-908.

24. Jockers R, Delagrange P, Dubocovich ML, Markus RP, Renault N, Tosini G, et al. Update on melatonin receptors: IUPHAR Review 20. Br J Pharmacol 2016;173:2702-2725.

25. Liu J, Clough SJ, Hutchinson AJ, Adamah-Biassi EB, Popovska-Gorevski M, Dubocovich ML. MT1 and MT2 melatonin receptors: a therapeutic perspective. Annu Rev Pharmacol Toxicol 2016;56:361-383.

26. Ekmekcioglu C. Melatonin receptors in humans: biological role and clinical relevance. Biomed Pharmacother 2006;60:97-108.

27. Reiter RJ, Tan DX, Manchester LC, Pilar Terron M, Flores LJ, Koppisepi S. Medical implications of melatonin: receptor-mediated and receptor-independent actions. Adv Med Sci 2007;52:11-28.

28. Wang H, Pu Y, Luo L, Li Y, Zhang Y, Cao Z. Membrane receptor-independent inhibitory effect of melatonin on androgen production in porcine theca cells. Theriogenology 2018;118:63-71.

29. Chen D, Mei Y, Kim N, Lan G, Gan CL, Fan F, et al. Melatonin directly binds and inhibits death-associated protein kinase 1 function in Alzheimer's disease. J Pineal Res 2020;69:e12665.

30. Koh PO. Melatonin prevents ischemic brain injury through activation of the mTOR/p70S6 kinase signaling pathway. Neurosci Lett 2008;444:7478.

31. Kodali VRR. Melatonin: the sleeping hormone. Int J Diabetes Dev Ctries 2017;37:1-3.

32. Iwasaki S, Nakazawa K, Sakai J, Kometani K, Iwashita M, Yoshimura Y, et al. Melatonin as a local regulator of human placental function. J Pineal Res 2005;39:261-265.
33. Nakazawa K, Kanakura Y, Kometani K, Iwasaki S, Yosimura Y. Study on melatonin in human and rat placental tissue. Placenta 1999;20 Suppl 1: 467-474.

34. Tan DX. Melatonin and brain. Curr Neuropharmacol 2010;8:161.

35. Carloni S, Facchinetti F, Pelizzi N, Buonocore G, Balduini W. Melatonin acts in synergy with hypothermia to reduce oxygen-glucose deprivationinduced cell death in rat hippocampus organotypic slice cultures. Neonatology 2018;114:364-371.

36. Motta-Teixeira LC, Machado-Nils AV, Battagello DS, Diniz GB, AndradeSilva J, Silva S Jr, et al. The absence of maternal pineal melatonin rhythm during pregnancy and lactation impairs offspring physical growth, neurodevelopment, and behavior. Horm Behav 2018;105:146-156.

37. Tan DX, Manchester LC, Reiter RJ, Qi WB, Zhang M, Weintraub ST, et al. Identification of highly elevated levels of melatonin in bone marrow: its origin and significance. Biochim Biophys Acta 1999;1472:206-214.

38. Jeong S. Molecular and cellular basis of neurodegeneration in Alzheimer's disease. Mol Cells 2017;40:613-620.

39. Tan SH, Karri V, Tay NWR, Chang KH, Ah HY, Ng PQ, et al. Emerging pathways to neurodegeneration: dissecting the critical molecular mechanisms in Alzheimer's disease, Parkinson's disease. Biomed Pharmacother 2019;111:765-777.

40. Callaway JK, Lawrence AJ, Jarrott B. AM-36, a novel neuroprotective agent, profoundly reduces reactive oxygen species formation and dopamine release in the striatum of conscious rats after endothelin-1-induced middle cerebral artery occlusion. Neuropharmacology 2003;44:787-800

41. Deutsch JC. Dehydroascorbic acid. J Chromatogr A 2000;881:299-307.

42. Kwon MO, Fischer F, Matthisson M, Herrling P. List of drugs in development for neurodegenerative diseases. Neurodegener Dis 2004;1:113-152.

43. Dhainaut A, Tizot A, Raimbaud E, Lockhart B, Lestage P, Goldstein S. Synthesis, structure, and neuroprotective properties of novel imidazolyl nitrones. J Med Chem 2000;43:2165-2175.

44. Kelso GF, Porteous CM, Coulter CV, Hughes G, Porteous WK, Ledgerwood EC, et al. Selective targeting of a redox-active ubiquinone to mitochondria within cells: antioxidant and antiapoptotic properties. J Biol Chem 2001;276:4588-4596.

45. Matsuoka Y, Jouroukhin Y, Gray AJ, Ma L, Hirata-Fukae C, Li HF, et al. A neuronal microtubule-interacting agent, NAPVSIPQ, reduces tau pathology and enhances cognitive function in a mouse model of Alzheimer's disease. J Pharmacol Exp Ther 2008;325:146-153.

46. Pieper CM, Roza AM, Henderson JD Jr, Zhu YR, Lai CS. Spatial distribution and temporal onset of NF-kB activation and inducible nitric oxide synthase within pancreatic islets in the pre-diabetic stage of genetic, diabetic-prone BB rats: attenuation by drug intervention decreases inflammatory cell infiltration and incidence of diabetes. Inflamm Res 2004;53:2230.

47. Jiang ZG, Lebowitz MS, Ghanbari HA. Neuroprotective activity of 3-aminopyridine-2-carboxaldehyde thiosemicarbazone (PAN-811), a cancer therapeutic agent. CNS Drug Rev 2006;12:77-90.

48. Pogačić Kramp V, Herrling P. List of drugs in development for neurodegenerative diseases: update June 2010. Neurodegener Dis 2011;8:44-94.

49. Valensi P, Le Devehat C, Richard JL, Farez C, Khodabandehlou T, Rosenbloom RA, et al. A multicenter, double-blind, safety study of QR-333 for the treatment of symptomatic diabetic peripheral neuropathy. A preliminary report. J Diabetes Complications 2005;19:247-253.

50. Baek IS, Kim TK, Seo JS, Lee KW, Lee YA, Cho J, et al. AAD-2004 attenuates progressive neuronal loss in the brain of Tg-betaCTF99/B6 mouse model of Alzheimer disease. Exp Neurobiol 2013;22:31-37.

51. Orrell RW. AEOL-10150 (Aeolus). Curr Opin Investig Drugs 2006;7:7080 .

52. Drummond NJ. Targeting a custom-engineered flavonoid to the mitochondria protects against acute oxidative stress [dissertation]. The University of Edinburgh, 2015.

53. Golden TR, Patel M. Catalytic antioxidants and neurodegeneration. Antioxid Redox Signal 2009;11:555-569.

54. Los M, Burek CJ, Stroh C, Benedyk K, Hug H, Mackiewicz A. Anticancer drugs of tomorrow: apoptotic pathways as targets for drug design. Drug Discov Today 2003;8:67-77.

55. Murphy FJ, Seery LT, Hayes I. Therapeutic approaches to the modulation of apoptosis. Essays Biochem 2003;39:131-153. 
56. Roy J, Drapeau SJ, Marx JC, inventors; Warsaw Orthopedic Inc., assignee. Methods for treating back or neck pain caused by NGF using a therapeutic agent consisting of ReN-1820, ALE-0540 and capsaicin. United States patent US 9,789,161 B2. 2017 Oct 17.

57. Lombard DB, Kohler W, Guo AH, Gendron C, Han M, Ding W, et al. High throughput small molecule screening reveals NRF2-dependent and -independent pathways of cellular stress resistance. bioRxiv 2019;778548 [preprint]. Available from https://doi.org/10.1101/778548.

58. Lee JY, Friedman JE, Angel I, Kozak A, Koh JY. The lipophilic metal chelator DP-109 reduces amyloid pathology in brains of human beta-amyloid precursor protein transgenic mice. Neurobiol Aging 2004;25:1315-1321.

59. Diener HC, Schneider D, Lampl Y, Bornstein NM, Kozak A, Rosenberg G. DP-b99, a membrane-activated metal ion chelator, as neuroprotective therapy in ischemic stroke. Stroke 2008;39:1774-1778.

60. Khare E, Fatima Z. Recent advances and current perspectives in treatment of Alzheimer's disease. Environ Conserv J 2020;21:183-186.

61. Nguyen TT, Giau VV, Vo TK. Current advances in transdermal delivery of drugs for Alzheimer's disease. Indian J Pharmacol 2017;49:145-154.

62. Woo JH, Park JW, Lee SH, Kim YH, Lee IK, Gabrielson E, et al. Dykellic acid inhibits phorbol myristate acetate-induced matrix metalloproteinase-9 expression by inhibiting nuclear factor kappa B transcriptional activity. Cancer Res 2003;63:3430-3434.

63. Heo JC, Park JY, Woo SU, Rho JR, Lee HJ, Kim SU, et al. Dykellic acid inhibits cell migration and tube formation by RhoA-GTP expression. Biol Pharm Bull 2006;29:2256-2259.

64. Laurent A, Hewitt K, Morris S, Bureau P, Boudreault A, Jarvis S, et al., inventors; Pharmascience Inc., assignee. IAP BIR domain binding compounds. United States patent US 9,284,350. 2016 Mar 15.

65. Poordad FF. IDN-6556 Idun Pharmaceuticals Inc. Curr Opin Investig Drugs 2004;5:1198-1204.

66. Lee H, Shin EA, Lee JH, Ahn D, Kim CG, Kim JH, et al. Caspase inhibitors: a review of recently patented compounds (2013-2015). Expert Opin Ther Pat 2018;28:47-59.

67. Statland JM, Moore D, Wang Y, Walsh M, Mozaffar T, Elman L, et al. Rasagiline for amyotrophic lateral sclerosis: a randomized, controlled trial. Muscle Nerve 2019;59:201-207.

68. Weintraub D, Hauser RA, Elm JJ, Pagan F, Davis MD, Choudhry A; MODERATO Investigators. Rasagiline for mild cognitive impairment in Parkinson's disease: a placebo-controlled trial. Mov Disord 2016;31:709714.

69. Staunton J, Jin X, Rufo DS, Monteiro M, inventors. Compositions and methods for the treatment of neurodegenerative diseases. World patent WO 2006/119329 A2. 2006 Nov 9.

70. Peters A. The effects of normal aging on myelin and nerve fibers: a review. J Neurocytol 2002;31:581-593.

71. Kujawa SG, Liberman MC. Adding insult to injury: cochlear nerve degeneration after "temporary" noise-induced hearing loss. J Neurosci 2009;29: 14077-14085.

72. Gaudet AD, Popovich PG, Ramer MS. Wallerian degeneration: gaining perspective on inflammatory events after peripheral nerve injury. J Neuroinflammation 2011;8:110.

73. Navarro X, Vivó M, Valero-Cabré A. Neural plasticity after peripheral nerve injury and regeneration. Prog Neurobiol 2007;82:163-201.

74. Resende R, Moreira PI, Proença T, Deshpande A, Busciglio J, Pereira C, et al. Brain oxidative stress in a triple-transgenic mouse model of Alzheimer disease. Free Radic Biol Med 2008;44:2051-2057.

75. Nishida Y, Yokota T, Takahashi T, Uchihara T, Jishage K, Mizusawa H. Deletion of vitamin E enhances phenotype of Alzheimer disease model mouse. Biochem Biophys Res Commun 2006;350:530-536.

76. Li F, Calingasan NY, Yu F, Mauck WM, Toidze M, Almeida CG, et al. Increased plaque burden in brains of APP mutant MnSOD heterozygous knockout mice. J Neurochem 2004;89:1308-1312.

77. Matsuoka Y, Picciano M, La Francois J, Duff K. Fibrillar beta-amyloid evokes oxidative damage in a transgenic mouse model of Alzheimer's disease. Neuroscience 2001;104:609-613.

78. Chinopoulos C, Adam-Vizi V. Calcium, mitochondria and oxidative stress in neuronal pathology. Novel aspects of an enduring theme. FEBS J 2006; 273:433-450.

79. Schipper HM. Redox neurology: visions of an emerging subspecialty. Ann
N Y Acad Sci 2004;1012:342-355

80. Li J, Wang C, Zhang JH, Cai JM, Cao YP, Sun XJ. Hydrogen-rich saline improves memory function in a rat model of amyloid-beta-induced Alzheimer's disease by reduction of oxidative stress. Brain Res 2010;1328: $152-161$.

81. Padurariu M, Ciobica A, Hritcu L, Stoica B, Bild W, Stefanescu C. Changes of some oxidative stress markers in the serum of patients with mild cognitive impairment and Alzheimer's disease. Neurosci Lett 2010;469:610.

82. Senoglu M, Nacitarhan V, Kurutas EB, Senoglu N, Altun I, Atli Y, et al. Intraperitoneal alpha-lipoic acid to prevent neural damage after crush injury to the rat sciatic nerve. J Brachial Plex Peripher Nerve Inj 2009;4:22.

83. Varija D, Kumar KP, Reddy KP, Reddy VK. Prolonged constriction of sciatic nerve affecting oxidative stressors \& antioxidant enzymes in rat. Indian J Med Res 2009;129:587-592.

84. Lee CL, Wang JJ, Pan TM. Red mold rice extract represses amyloid beta peptide-induced neurotoxicity via potent synergism of anti-inflammatory and antioxidative effect. Appl Microbiol Biotechnol 2008;79:829-841.

85. Jang MH, Jung SB, Lee MH, Kim CJ, Oh YT, Kang I, et al. Melatonin attenuates amyloid beta25-35-induced apoptosis in mouse microglial BV2 cells. Neurosci Lett 2005;380:26-31.

86. Lee SY, Lee JW, Lee H, Yoo HS, Yun YP, Oh KW, et al. Inhibitory effect of green tea extract on beta-amyloid-induced PC12 cell death by inhibition of the activation of NF-kappaB and ERK/p38 MAP kinase pathway through antioxidant mechanisms. Brain Res Mol Brain Res 2005;40:45-54.

87. Hashimoto M, Tanabe Y, Fujii Y, Kikuta T, Shibata H, Shido O. Chronic administration of docosahexaenoic acid ameliorates the impairment of spatial cognition learning ability in amyloid beta-infused rats. J Nutr 2005; 135:549-555.

88. Olcese JM, Cao C, Mori T, Mamcarz MB, Maxwell A, Runfeldt MJ, et al. Protection against cognitive deficits and markers of neurodegeneration by long-term oral administration of melatonin in a transgenic model of $\mathrm{Al}-$ zheimer disease. J Pineal Res 2009;47:82-96.

89. Ionov M, Burchell V, Klajnert B, Bryszewska M, Abramov AY. Mechanism of neuroprotection of melatonin against beta-amyloid neurotoxicity. Neuroscience 2011;180:229-237.

90. Rosales-Corral S, Tan DX, Reiter RJ, Valdivia-Velázquez M, MartínezBarboza G, Acosta-Martínez JP, et al. Orally administered melatonin reduces oxidative stress and proinflammatory cytokines induced by amyloid-beta peptide in rat brain: a comparative, in vivo study versus vitamin C and E. J Pineal Res 2003;35:80-84.

91. Jesudason EP, Baben B, Ashok BS, Masilamoni JG, Kirubagaran R, Jebaraj WC, et al. Anti-inflammatory effect of melatonin on A beta vaccination in mice. Mol Cell Biochem 2007;298:69-81.

92. Shen YX, Xu SY, Wei W, Wang XL, Wang H, Sun X. Melatonin blocks rat hippocampal neuronal apoptosis induced by amyloid beta-peptide 25-35. J Pineal Res 2002;32:163-167.

93. Feng Z, Qin C, Chang Y, Zhang JT. Early melatonin supplementation alleviates oxidative stress in a transgenic mouse model of Alzheimer's disease. Free Radic Biol Med 2006;40:101-109.

94. Olivieri G, Otten U, Meier F, Baysang G, Dimitriades-Schmutz B, MüllerSpahn F, et al. Beta-amyloid modulates tyrosine kinase B receptor expression in SHSY5Y neuroblastoma cells: influence of the antioxidant melatonin. Neuroscience 2003;120:659-665.

95. Anderson KN, Jamieson S, Graham AJ, Shneerson JM. REM sleep behaviour disorder treated with melatonin in a patient with Alzheimer's disease. Clin Neurol Neurosurg 2008;110:492-495.

96. Shokouhi G, Tubbs RS, Shoja MM, Hadidchi S, Ghorbanihaghjo A, Roshangar L, et al. Neuroprotective effects of high-dose vs low-dose melatonin after blunt sciatic nerve injury. Childs Nerv Syst 2008;24:111-117.

97. Rogério F, Teixeira SA, de Rezende AC, de Sá RC, de Souza Queiroz L, De Nucci G, et al. Superoxide dismutase isoforms 1 and 2 in lumbar spinal cord of neonatal rats after sciatic nerve transection and melatonin treatment. Brain Res Dev Brain Res 2005;154:217-225.

98. Stavisky RC, Britt JM, Zuzek A, Truong E, Bittner GD. Melatonin enhances the in vitro and in vivo repair of severed rat sciatic axons. Neurosci Lett 2005;376:98-101.

99. Turgut M, Uyanikgil Y, Baka M, Tunç AT, Yavaşoğlu A, Yurtseven ME, et al. Pinealectomy exaggerates and melatonin treatment suppresses neuro- 
ma formation of transected sciatic nerve in rats: gross morphological, histological and stereological analysis. J Pineal Res 2005;38:284-291.

100. Zencirci SG, Bilgin MD, Yaraneri H. Electrophysiological and theoretical analysis of melatonin in peripheral nerve crush injury. J Neurosci Methods 2010;191:277-282.

101. Lindholm D, Wootz H, Korhonen L. ER stress and neurodegenerative diseases. Cell Death Differ 2006;13:385-392.

102. Rayavarapu S, Coley W, Nagaraju K. Endoplasmic reticulum stress in skeletal muscle homeostasis and disease. Curr Rheumatol Rep 2012;14: 238-243.

103. Unterberger U, Höftberger R, Gelpi E, Flicker H, Budka H, Voigtländer T. Endoplasmic reticulum stress features are prominent in Alzheimer disease but not in prion diseases in vivo. J Neuropathol Exp Neurol 2006;65: 348-357.

104. Lee JH, Won SM, Suh J, Son SJ, Moon GJ, Park UJ, et al. Induction of the unfolded protein response and cell death pathway in Alzheimer's disease, but not in aged Tg2576 mice. Exp Mol Med 2010;42:386-394.

105. Hoozemans JJ, van Haastert ES, Nijholt DA, Rozemuller AJ, Eikelenboom $\mathrm{P}$, Scheper W. The unfolded protein response is activated in pretangle neurons in Alzheimer's disease hippocampus. Am J Pathol 2009;174: 1241-1251.

106. Slodzinski H, Moran LB, Michael GJ, Wang B, Novoselov S, Cheetham ME, et al. Homocysteine-induced endoplasmic reticulum protein (herp) is up-regulated in parkinsonian substantia nigra and present in the core of Lewy bodies. Clin Neuropathol 2009;28:333-343.

107. Carnemolla A, Fossale E, Agostoni E, Michelazzi S, Calligaris R, De Maso $\mathrm{L}$, et al. Rrs1 is involved in endoplasmic reticulum stress response in Huntington disease. J Biol Chem 2009;284:18167-18173.

108. Ling ZQ, Tian Q, Wang L, Fu ZQ, Wang XC, Wang Q, et al. Constant illumination induces Alzheimer-like damages with endoplasmic reticulum involvement and the protection of melatonin. J Alzheimers Dis 2009;16: 287-300.

109. Lin AM, Fang SF, Chao PL, Yang CH. Melatonin attenuates arsenite-induced apoptosis in rat brain: involvement of mitochondrial and endoplasmic reticulum pathways and aggregation of alpha-synuclein. J Pineal Res 2007;43:163-171.

110. Kang EB, Kwon IS, Koo JH, Kim EJ, Kim CH, Lee J, et al. Treadmill exercise represses neuronal cell death and inflammation during $A \beta$-induced ER stress by regulating unfolded protein response in aged presenilin $2 \mathrm{mu}-$ tant mice. Apoptosis 2013;18:1332-1347.

111. Lin YW, Chen TY, Hung CY, Tai SH, Huang SY, Chang CC, et al. Melatonin protects brain against ischemia/reperfusion injury by attenuating endoplasmic reticulum stress. Int J Mol Med 2018;42:182-192.

112. Lane N. Mitochondrial disease: powerhouse of disease. Nature 2006;440: 600-602.

113. López A, García JA, Escames G, Venegas C, Ortiz F, López LC, et al. Melatonin protects the mitochondria from oxidative damage reducing oxygen consumption, membrane potential, and superoxide anion production. J Pineal Res 2009;46:188-198.

114. Escames G, López LC, Ortiz F, López A, García JA, Ros E, et al. Attenuation of cardiac mitochondrial dysfunction by melatonin in septic mice. FEBS I 2007;274:2135-2147.

115. Rodríguez MI, Carretero M, Escames G, López LC, Maldonado MD, Tan DX, et al. Chronic melatonin treatment prevents age-dependent cardiac mitochondrial dysfunction in senescence-accelerated mice. Free Radic Res 2007;41:15-24.

116. Hardeland R, Cardinali DP, Srinivasan V, Spence DW, Brown GM, PandiPerumal SR. Melatonin--a pleiotropic, orchestrating regulator molecule. Prog Neurobiol 2011;93:350-384.

117. Hardeland R. Neuroprotection by radical avoidance: search for suitable agents. Molecules 2009;14:5054-5102.

118. Dungel P, Mittermayr R, Haindl S, Osipov A, Wagner C, Redl H, et al. Illumination with blue light reactivates respiratory activity of mitochondria inhibited by nitric oxide, but not by glycerol trinitrate. Arch Biochem Biophys 2008;471:109-115.

119. Hardeland R, Poeggeler B, Niebergall R, Zelosko V. Oxidation of melatonin by carbonate radicals and chemiluminescence emitted during pyrrole ring cleavage. J Pineal Res 2003;34:17-25.

120. Hardeland R. Antioxidative protection by melatonin: multiplicity of mech- anisms from radical detoxification to radical avoidance. Endocrine 2005 27:119-130

121. Reiter RJ, Tan DX, Burkhardt S. Reactive oxygen and nitrogen species and cellular and organismal decline: amelioration with melatonin. Mech Ageing Dev 2002;123:1007-1019.

122. Reiter RJ. Interactions of the pineal hormone melatonin with oxygen-centered free radicals: a brief review. Braz J Med Biol Res 1993;26:1141-1155.

123. Yon JH, Daniel-Johnson J, Carter LB, Jevtovic-Todorovic V. Anesthesia induces neuronal cell death in the developing rat brain via the intrinsic and extrinsic apoptotic pathways. Neuroscience 2005;135:815-827.

124. Henry-Mowatt J, Dive C, Martinou JC, James D. Role of mitochondrial membrane permeabilization in apoptosis and cancer. Oncogene 2004;23: 2850-2860.

125. Halestrap AP, McStay GP, Clarke SJ. The permeability transition pore complex: another view. Biochimie 2002;84:153-166.

126. Reiter RJ, Tan DX, Rosales-Corral S, Galano A, Jou MJ, Acuna-Castroviejo D. Melatonin mitigates mitochondrial meltdown: interactions with SIRT3. Int J Mol Sci 2018;19:2439.

127. Martín M, Macías M, Escames G, León J, Acuña-Castroviejo D. Melatonin but not vitamins $\mathrm{C}$ and $\mathrm{E}$ maintains glutathione homeostasis in t-butyl hydroperoxide-induced mitochondrial oxidative stress. FASEB J 2000; 14:1677-1679.

128. León J, Acuña-Castroviejo D, Escames G, Tan DX, Reiter RJ. Melatonin mitigates mitochondrial malfunction. J Pineal Res 2005;38:1-9.

129. Martín M, Macías M, León J, Escames G, Khaldy H, Acuña-Castroviejo D. Melatonin increases the activity of the oxidative phosphorylation enzymes and the production of ATP in rat brain and liver mitochondria. Int J Biochem Cell Biol 2002;34:348-357.

130. Acuna-Castroviejo D, Escames G, Rodriguez MI, Lopez LC. Melatonin role in the mitochondrial function. Front Biosci 2007;12:947-963.

131. Kilic E, Kilic U, Yulug B, Hermann DM, Reiter RJ. Melatonin reduces disseminate neuronal death after mild focal ischemia in mice via inhibition of caspase- 3 and is suitable as an add-on treatment to tissue-plasminogen activator. J Pineal Res 2004;36:171-176.

132. Yang J, Liu X, Bhalla K, Kim CN, Ibrado AM, Cai J, et al. Prevention of apoptosis by Bcl-2: release of cytochrome $\mathrm{c}$ from mitochondria blocked. Science 1997;275:1129-1132.

133. Jou MJ, Peng TI, Reiter RJ, Jou SB, Wu HY, Wen ST. Visualization of the antioxidative effects of melatonin at the mitochondrial level during oxidative stress-induced apoptosis of rat brain astrocytes. J Pineal Res 2004;37: 55-70.

134. Kroemer G, Petit P, Zamzami N, Vayssière J-L, Mignotte B. The biochemistry of programmed cell death. FASEB J 1995;9:1277-1287.

135. Chovancova B, Hudecova S, Lencesova L, Babula P, Rezuchova I, Penesova A, et al. Melatonin-induced changes in cytosolic calcium might be responsible for apoptosis induction in tumour cells. Cell Physiol Biochem 2017;44:763-777.

136. Ouyang L, Shi Z, Zhao S, Wang FT, Zhou TT, Liu B, et al. Programmed cell death pathways in cancer: a review of apoptosis, autophagy and programmed necrosis. Cell Prolif 2012;45:487-498.

137. Miura M. Apoptotic and non-apoptotic caspase functions in neural development. Neurochem Res 2011;36:1253-1260.

138. Ghavami S, Shojaei S, Yeganeh B, Ande SR, Jangamreddy JR, Mehrpour $\mathrm{M}$, et al. Autophagy and apoptosis dysfunction in neurodegenerative disorders. Prog Neurobiol 2014;112:24-49.

139. Yoshida H, Kong YY, Yoshida R, Elia AJ, Hakem A, Hakem R, et al. Apaf1 is required for mitochondrial pathways of apoptosis and brain development. Cell 1998;94:739-750.

140. Cecconi F, Alvarez-Bolado G, Meyer BI, Roth KA, Gruss P. Apaf1 (CED-4 homolog) regulates programmed cell death in mammalian development. Cell 1998;94:727-737.

141. Motoyama N, Wang F, Roth KA, Sawa H, Nakayama K, Nakayama K, et al. Massive cell death of immature hematopoietic cells and neurons in Bclx-deficient mice. Science 1995;267:1506-1510.

142. Naseem M, Parvez S. Role of melatonin in traumatic brain injury and spinal cord injury. ScientificWorldJournal 2014;2014:586270.

143. Khalatbary AR, Ahmadvand H. Anti-inflammatory effect of the epigallocatechin gallate following spinal cord trauma in rat. Iran Biomed J 2011; 15:31-37. 
144. Cheung RT. The utility of melatonin in reducing cerebral damage resulting from ischemia and reperfusion. J Pineal Res 2003;34:153-160.

145. Baydas G, Reiter RJ, Akbulut M, Tuzcu M, Tamer S. Melatonin inhibits neural apoptosis induced by homocysteine in hippocampus of rats via inhibition of cytochrome $\mathrm{c}$ translocation and caspase-3 activation and by regulating pro- and anti-apoptotic protein levels. Neuroscience 2005;135: 879-886.

146. Koh PO. Melatonin attenuates the focal cerebral ischemic injury by inhibiting the dissociation of pBad from 14-3-3. J Pineal Res 2008;44:101-106.

147. Shi L, Liang F, Zheng J, Zhou K, Chen S, Yu J, et al. Melatonin regulates apoptosis and autophagy via ROS-MST1 pathway in subarachnoid hemorrhage. Front Mol Neurosci 2018;11:93.

148. Das G, Shravage BV, Baehrecke EH. Regulation and function of autophagy during cell survival and cell death. Cold Spring Harb Perspect Biol 2012; 4:a008813.

149. Carloni S, Girelli S, Scopa C, Buonocore G, Longini M, Balduini W. Activation of autophagy and Akt/CREB signaling play an equivalent role in the neuroprotective effect of rapamycin in neonatal hypoxia-ischemia. Autophagy 2010;6:366-377.

150. Puyal J, Vaslin A, Mottier V, Clarke PG. Postischemic treatment of neonatal cerebral ischemia should target autophagy. Ann Neurol 2009;66:378389.

151. Wen YD, Sheng R, Zhang LS, Han R, Zhang X, Zhang XD, et al. Neuronal injury in rat model of permanent focal cerebral ischemia is associated with activation of autophagic and lysosomal pathways. Autophagy 2008;4:
762-769.

152. Park S, Lee SK, Park K, Lee Y, Hong Y, Lee S, et al. Beneficial effects of endogenous and exogenous melatonin on neural reconstruction and functional recovery in an animal model of spinal cord injury. J Pineal Res 2012; 52:107-119.

153. Guo Y, Wang J, Wang Z, Yang Y, Wang X, Duan Q. Melatonin protects N2a against ischemia/reperfusion injury through autophagy enhancement. J Huazhong Univ Sci Technolog Med Sci 2010;30:1-7.

154. Zheng Y, Hou J, Liu J, Yao M, Li L, Zhang B, et al. Inhibition of autophagy contributes to melatonin-mediated neuroprotection against transient focal cerebral ischemia in rats. J Pharmacol Sci 2014;124:354-364.

155. Tang P, Hou H, Zhang L, Lan X, Mao Z, Liu D, et al. Autophagy reduces neuronal damage and promotes locomotor recovery via inhibition of apoptosis after spinal cord injury in rats. Mol Neurobiol 2014;49:276-287.

156. Degenhardt K, Mathew R, Beaudoin B, Bray K, Anderson D, Chen G, et al. Autophagy promotes tumor cell survival and restricts necrosis, inflammation, and tumorigenesis. Cancer Cell 2006;10:51-64.

157. Chen J, Wang L, Wu C, Hu Q, Gu C, Yan F, et al. Melatonin-enhanced autophagy protects against neural apoptosis via a mitochondrial pathway in early brain injury following a subarachnoid hemorrhage. J Pineal Res 2014;56:12-19.

158. Shang J, Deguchi K, Yamashita T, Ohta Y, Zhang H, Morimoto N, et al. Antiapoptotic and antiautophagic effects of glial cell line-derived neurotrophic factor and hepatocyte growth factor after transient middle cerebral artery occlusion in rats. J Neurosci Res 2010;88:2197-2206. 